\title{
Variations in feeding behaviour of high-yielding dairy cows in relation to parity during early to peak lactation
}

\author{
OSMAN AZIZI ${ }^{1}$, LUTZ HASSELMANN² and OTTO KAUFMANN²
}

\begin{abstract}
'Department of Animal Science, College of Agriculture, University of Kurdistan, Sanandaj, Iran, ${ }^{2}$ Division of Animal Husbandry and Technology, Department of Crop an Animal Science, Agricultural and Horticultural Faculty, Humboldt-Universität zu Berlin, Germany
\end{abstract}

\section{Abstract}

The objective of this study was to compare the feeding behaviour of high-yielding dairy cows in relation to parity during early to peak lactation and to determine whether or not there was any relationship between variables describing their feeding behaviour and total feed intake. Information concerning feed intake of each individual dairy cow is especially valuable for the herd management, particularly in early lactation. However, technical requirements for implementation are rarely given. Therefore, relationships between feed intake and time-related feeding behaviour parameters are of special interest. Time-related parameters could be recorded on farm conditions adapted sensor technology. Seventy high-yielding lactating dairy cows in different parities (23 in the 1st lactation, 17 in the 2nd lactation, and 30 in the 3rd-and-more-lactation) with an average of $11000 \mathrm{~kg}$ milk yield per year were fed using automatic feeders from the 2nd to the 15th week of lactation. 222231 recorded visits were analysed in three equal periods (period $1=7-39$, period $2=40-72$, and period $3=73-105$ days in milk [DIM]) during early to peak lactation. Visits were clustered in meals based on the estimated meal criterion (28.5 $\mathrm{min}$ ). The present study yielded the following values for meal frequency, number of visits per meal, meal duration, meal size, daily mealtime, daily dry matter intake (DMI), and feeding rate over the course of the study were $7.61 \pm 1.7$ (mean \pm SD) meals/d, $4.02 \pm 1.68 \mathrm{visits} / \mathrm{meal}, 37.07 \pm 13.77 \mathrm{~min} / \mathrm{meal}, 2.96 \pm 0.92 \mathrm{~kg} \mathrm{DM} / \mathrm{meal}, 272.18 \pm 82.14$ $\mathrm{min} / \mathrm{d}, 21.46 \pm 4.29 \mathrm{~kg} \mathrm{DM} / \mathrm{d}$, and $85.56 \pm 28.77 \mathrm{~g} \mathrm{DM} / \mathrm{min}$, respectively. Younger cows had more meals per day, more number of visits per meal, longer daily mealtime but a smaller meal size, lower daily DMl, and lower feeding rate compared to older cows $(P<0.001)$. Meal duration and meal size were highly related to the number of visits at feeder per meal $\left(R^{2}=0.55-0.63 ; P<0.001, R^{2}=0.25-0.39 ; P<0.001\right.$ respectively). In addition, meal size was highly related to meal duration $\left(R^{2}=0.59-0.72 ; P<0.001\right)$. Results from this study, which analysed data based on meal criterion, showed a higher correlation between the selected parameters of feeding behaviour and feed intake. The high correlation between meal duration and meal size could be used to estimate feed intake.

Keywords: feeding behaviour, feed intake, parity, dairy cow 


\section{Zusammenfassung}

\section{Variationen von Merkmalen des Futteraufnahmeverhaltens hochleistender Milchkühe im Verlauf der Früh- und Hochlaktation}

Das Ziel der Untersuchungen bestand darin, das Fressverhalten von hochleistenden Kühen verschiedener Laktationen zu untersuchen. Der Schwerpunkt der Analysen konzentrierte sich auf die Beziehungen verschiedener Variablen des Fressverhaltens und der Futteraufnahme in der Frühlaktation. Es ging dabei um die grundsätzliche Frage, ob zeitbezogene Merkmale des Fressverhaltens dazu genutzt werden können, um Veränderungen in der Futteraufnahme zu erkennen. Wenn das zuträfe, wäre das eine Basis für die technische Entwicklung von praxisrelevanten Systemen zum Monitoring der Futteraufnahme. Für die Versuche wurden 70 hochleistende Kühe (durchschnittliche Jahresleistung $11000 \mathrm{~kg}$ Milch) der Rasse Deutsche Holstein (23 in der ersten Laktation, 17 in der zweiten und 30 in der dritten und folgenden Laktationen) genutzt. Die Fütterung erfolgte von der zweiten bis 15. Laktationswoche an Einzelfütterungsautomaten (Wiegetröge mit elektronischer Tiererkennung). Insgesamt wurden 222231 Messungen während der Fressplatzbesuche, aufgeteilt in drei gleichlange Abschnitte (Periode 1: 7. bis 39., Periode 2: 40. bis 72., Periode 3: 73. bis 105. Laktationstag), ausgewertet. Die Fressplatzbesuche wurden zusammengefasst in Mahlzeiten, basierend auf der Kalkulation eines »Mahlzeiten-Kriteriums« (28,5 min.). Die Untersuchungen führten über die Gesamtdauer des Versuches zu folgenden Ergebnissen: Mahlzeiten/Tag: 7,61 $\pm 1,7$ (Mittelwert \pm SD), Besuche/Mahlzeit: 4,02 $\pm 1,68$, Dauer der Mahlzeiten: 37,07 $\pm 13,77$ min, Trockenmasseaufnahme/Mahlzeit, 2,96 $\pm 0,92 \mathrm{~kg}$, Gesamtfresszeit/Tag: 272,18 $\pm 82,14$ min, Trockenmasseaufnahme/Tag: 21,46 $\pm 4,29 \mathrm{~kg}$, Fressgeschwindigkeit: $85,56 \pm 28,77 \mathrm{~g}$ Trockenmasse/min. Bei jüngeren Kühen waren mehr Mahlzeiten pro Tag, mehr Besuche je Mahlzeit sowie eine längere tägliche Gesamtfresszeit zu verzeichnen, aber andererseits eine geringere Trockenmasseaufnahme/Mahlzeit, eine geringere tägliche Trockenmasseaufnahme und eine signifikant $(P<0,001)$ niedrigere Fressgeschwindigkeit im Vergleich zu älteren Kühen. Mahlzeitdauer und Trockenmasseaufnahme/Mahlzeit standen in enger Relation zur Anzahl der Besuche am Fressplatz je Mahlzeit $\left(R^{2}=0,55-0,63 ; P<0,001\right.$ bzw. $\left.R^{2}=0,25-0,39 ; P<0,001\right)$. Außerdem war eine enge Beziehung zwischen Trockenmasseaufnahme/Mahlzeit und Mahlzeitdauer $\left(R^{2}=0,59-0,72 ; P<0,001\right)$ zu verzeichnen.

Schlüsselwörter: Futteraufnahmeverhalten, Futteraufnahme, Laktationszahl, Milchkuh

\section{Introduction}

Feeding behaviour is an area of research which truly links nutritional and behavioural sciences. Information concerning the feed intake of each individual dairy cow is especially valuable for herd management. However, the technical equipment to measure the feed intake of each individual cow is expensive. Therefore, relationships between feeding behaviour parameters, which can be recorded on farm conditions adapted with sensor technology, and feed intake are of special interest. The average daily intake of cows is frequently considered to be the result of one or more constraints, especially during early lactation (TOLKAMP et al. 2000). Average daily intake is, at least in a purely 
formal sense, the result of the average number of feeding bouts per day and the average size of those bouts. If limited intake is a result of time spans shorter than a day, then a study of short-term feeding behaviour could improve the understanding and prediction of daily intake (DADO and ALLEN 1994, FORBES 1985, GILL and ROMNEY 1995). The feeding behaviour of most animals can be recorded as events that include bites or visits to a feeder (NIELSEN 1999). TOLKAMP et al. $(1998,2000)$ and DE VRIES et al. (2003) argued that dairy cows divide their feeding time into a series of meals separated by non-feeding intervals. These researchers developed a model to define the meal criterion by using the distribution of a large sample of intervals between visits to the feeders. The meal criterion is defined as the longest non-feeding interval that is still considered an interval within a meal.

Previous investigations of the effects of parity and stage of lactation on changes in feeding behaviour have been limited to cows during early lactation. DE VRIES et al. (2003) reported that cows were highly consistent in some characteristics of feeding behaviour. In a previous study (KAUFMANN et al. 2007), was analysed all visits to a feeder without calculating meal criterion, and in this paper, was analysed the feeding behaviour and feed intake parameters after clustering the visits in meals based on the estimated meal criterion. The objective of the recent study was to compare the feeding behaviour and feed intake parameters of high-producing dairy cows in relation to their parity during early to peak lactation and to determine whether or not there was a relationship between these variables.

\section{Material and methods}

\section{Animal, housing and feeding}

Data were collected from a feeding experiment, which was performed in the Centre of Research for Animal Husbandry and Technology of the Regional Office for Agriculture and Horticulture (Iden, Sachsen-Anhalt, Germany) from 10 July 2005 to 16 January 2006. For this study, data were collected from 70 lactating dairy cows: 23 cows in the 1st lactation, 17 cows in the 2nd lactation, and 30 cows in the 3rd-and-more-lactation (3rd to 7th lactation), with a body weight (BW) of $572 \pm 42$ (mean \pm SD), $637 \pm 38$, and $716 \pm 56 \mathrm{~kg}$, respectively. Fifteen cows (in the 1st lactation) were crossbreds of German Holstein Friesian and Brown Swiss, and 55 cows were purebred German Holstein Friesian. The cows were housed in a free-stall barn. The ratio between cows and feeder was $2: 1$. Feeder units were equipped with electronic identification of individual cows and an electronic control. The cows could enter any feeder. Cows were fed ad libitum a total mixed ration (TMR) (based on the objectives of a feeding experiment) with an average of $6.99 \mathrm{MJ} \mathrm{NEL} / \mathrm{kg}$ dry matter (DM), $16.68 \%$ crude protein and $17.46 \%$ crude fibre. The feeders were accessible throughout the day, except during milking and cleaning (07:00 to 08:00 h). Chemical analyses of the ration were conducted weekly. The cows were milked three times a day $(04: 00,12: 00$, and 20:00 h) and the daily milk yield was recorded for each individual cow over the course of the study. Throughout the study, the animals had an average milk yield of $38.83 \pm 7.96$ (mean \pm SD) $\mathrm{kg} / \mathrm{d}$ with $3.93 \% \pm 0.60$ fat and $3.24 \% \pm 0.26$ protein. 


\section{Measurements}

Individual analyses of feeding behaviour and feed intake were carried out by using an automatic feeder and electronic identification of individual cows. Each feeder was equipped with an access gate, which could be programmed to allow a specific cow to access a trough, and two infrared sensors, which recorded the presence of a cow in the feeder. All experimental animals were fitted with a passive transponder, which was encased in a plastic ear tag and attached to the bottom of the collar. The time of the beginning and end of each visit was recorded. Additionally, the weight of the trough at the beginning and end of the visit was recorded. A visit was defined as the time spent by an individual cow with her head in one of the troughs, regardless of how the cow spent that time. Intervals between visits were calculated for each cow from the end of a visit to the beginning of the next. The minimum interval was $1 \mathrm{~s}$. To determine whether a visit was part of the previous meal, part of the next meal or formed a meal itself, meal criteria were calculated. Visits were grouped into meals. Individual meal criteria were calculated for each cow and a pooled criterion was calculated using the intervals from all cows for the whole experimental period. Meal criteria were calculated based on methods from TOLKAMP et al. (1998) and DE VRIES et al. (2003) by fitting a mixture of two normal distributions to the distributions of natural logarithm (Ln)-transformed lengths of intervals between visits. Maximum likelihood estimation was used to fit these mixture distributions. In the present study, the 1 st distribution showed the intervals within one meal and the 2 nd one represented those between meals. The meal criterion was determined as the point at which the distribution curve of inter-meal intervals intersected the distribution curve of intra-meal intervals. Based on the meal criteria, meal frequency (meals/d) was calculated by counting the number of intervals per day that exceeded the length of the meal criterion and adding one. The meal duration ( $\mathrm{min} / \mathrm{meal}$ ) was calculated as the time from the beginning of the $1 \mathrm{st}$ feeding event until an interval between events that exceeded the meal criterion - this interval was not included in the calculation. The daily mealtime $(\mathrm{min} / \mathrm{d})$ was simply the sum of the meal durations in a day. The meal size $(\mathrm{kg} / \mathrm{meal})$ was the total amount of feed ingested during each meal. The daily DMI $(\mathrm{kg} / \mathrm{d})$ was the sum of the meal sizes in a day. To determine if the use of a pooled meal criterion is appropriate for future calculations, the daily estimates of feeding behaviour characteristics by using the individual meal criteria where compared with those based on the pooled criterion.

\section{Statistical analysis}

The individual animal was considered as the observational unit in all analyses. All data were analysed using PROC MIXED in SAS (SAS INSTITUTE 2003), including a repeated statement with day as repeated measures and animal as repeated subject. For each animal, meal frequency (meal/d), meal duration ( $\mathrm{min} / \mathrm{meal})$, meal size $(\mathrm{kg} / \mathrm{meal})$, daily mealtime $(\mathrm{min} / \mathrm{d})$, daily DMI $(\mathrm{kg} / \mathrm{d})$, and feeding rate $(\mathrm{gDM} / \mathrm{min})$ was calculated. A total of 222231 recorded visits were analysed. To determine effects of stage of lactation, data were analyzed in three equal periods (period $1=7-39$, period $2=40-72$, and period $3=$ 73-105 days in milk [DIM]) during early to peak of lactation. To test for effects of parity and stage of lactation on feeding behaviour characteristics and feed intake parameters, was used a linear model: 


$$
Y_{i j k}=\mu+P A_{i}+\sigma_{i j}+P E_{k}+(P A \cdot P E)_{i k}+\varepsilon_{i j k}
$$

where $Y_{i j k}$ is the observation of the interested variable, $\mu$ is the overall mean, $\mathrm{PA}_{\mathrm{i}}$ is the effect of parity $i(i=1,2$, and 3$), \sigma_{i j}$ is the random error with mean 0 and variance $\sigma_{\delta}^{2}$, the variance between animals within parity and it is equal to the covariance between repeated measurements within animals, $P E_{k}$ is the effect of period $k(k=1,2$, and 3$)$, $(P A \cdot P E)_{i k}$ is the interaction between parity $i$ and period $k, \varepsilon_{\mathrm{jik}}$ is the random error with the mean 0 and variance $\sigma^{2}$, the variance between measurements within animals. Correlations between feeding behaviour characteristics and feed intake were calculated using the regression procedure of SAS (SAS INSTITUTE 2003).

\section{Results}

Meal criteria were calculated for each cow over the course of the study and varied among cows from $13 \mathrm{~min}$ to $53 \mathrm{~min}$ with an average of $27.27 \mathrm{~min}(\mathrm{SD}=6.72)$. The meal criterion from pooled data (for all cows and over the course of the study) was 28.5 min (Figure 1). The correlation between pooled and individual estimates for meal frequency and daily mealtime is illustrated in Figure 2. The estimates of all parameters using both an individual criterion and a pooled criterion were very similar. Therefore, the pooled meal criterion in all subsequent analyses was used. Based on this meal criterion, an average meal frequency of $7.61 \pm 1.7$ (mean $\pm S D$ ) meals/d was calculated. The cows realised $4.02 \pm 1.68$ visits per meal with an average of duration of $37.07 \pm 13.77 \mathrm{~min} / \mathrm{meal}$. The total daily mealtime was $272.18 \pm 82.14 \mathrm{~min} / \mathrm{d}$. Following parameters of feed intake where determined: meal size $2.96 \pm 0.92 \mathrm{~kg} / \mathrm{meal}$, daily DMl $21.46 \pm 4.29 \mathrm{~kg} / \mathrm{d}$, and feeding rate $85.56 \pm 28.77 \mathrm{gDM} / \mathrm{min}$.

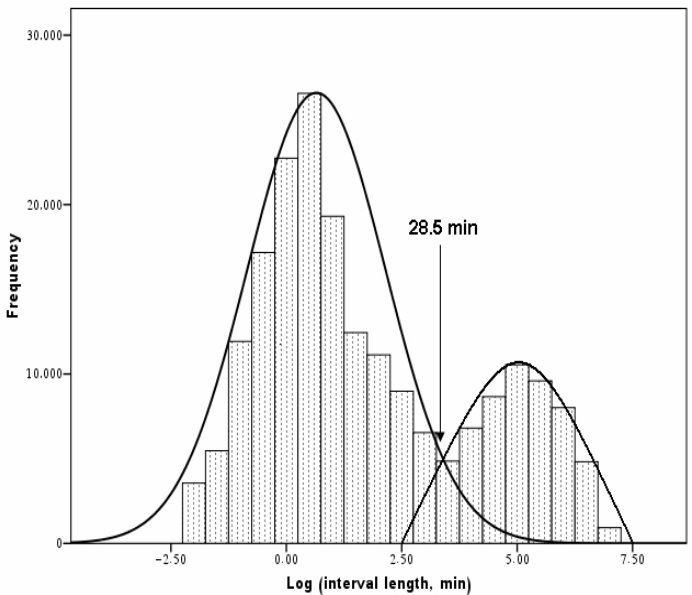

Figure 1

Log (interval length, min)

Frequency distribution of interval length between visits to feeder. The frequency distribution of the logtransformed intervals fitted with a mixture of two normal distributions, effectively separating the within meal interval and the between meal intervals. The meal criterion is the log interval at which the two curves intersect. Frequencies were divided by class width ( 0.5 log-units).

Frequenzverteilung der Intervallänge der Aufenthaltsdauer am Fressplatz. Die Frequenzverteilung der logarithmierten Intervalle basiert auf einer Mischung aus den zwei Normalverteilungen und der effektiven Separation innerhalb und zwischen den Mahlzeitenintervallen. Das Mahlzeitenkriterium ergibt sich aus dem Schnittpunkt der logarithmierten Intervalle (Klassenbreite 0,5 log-Einheiten). 

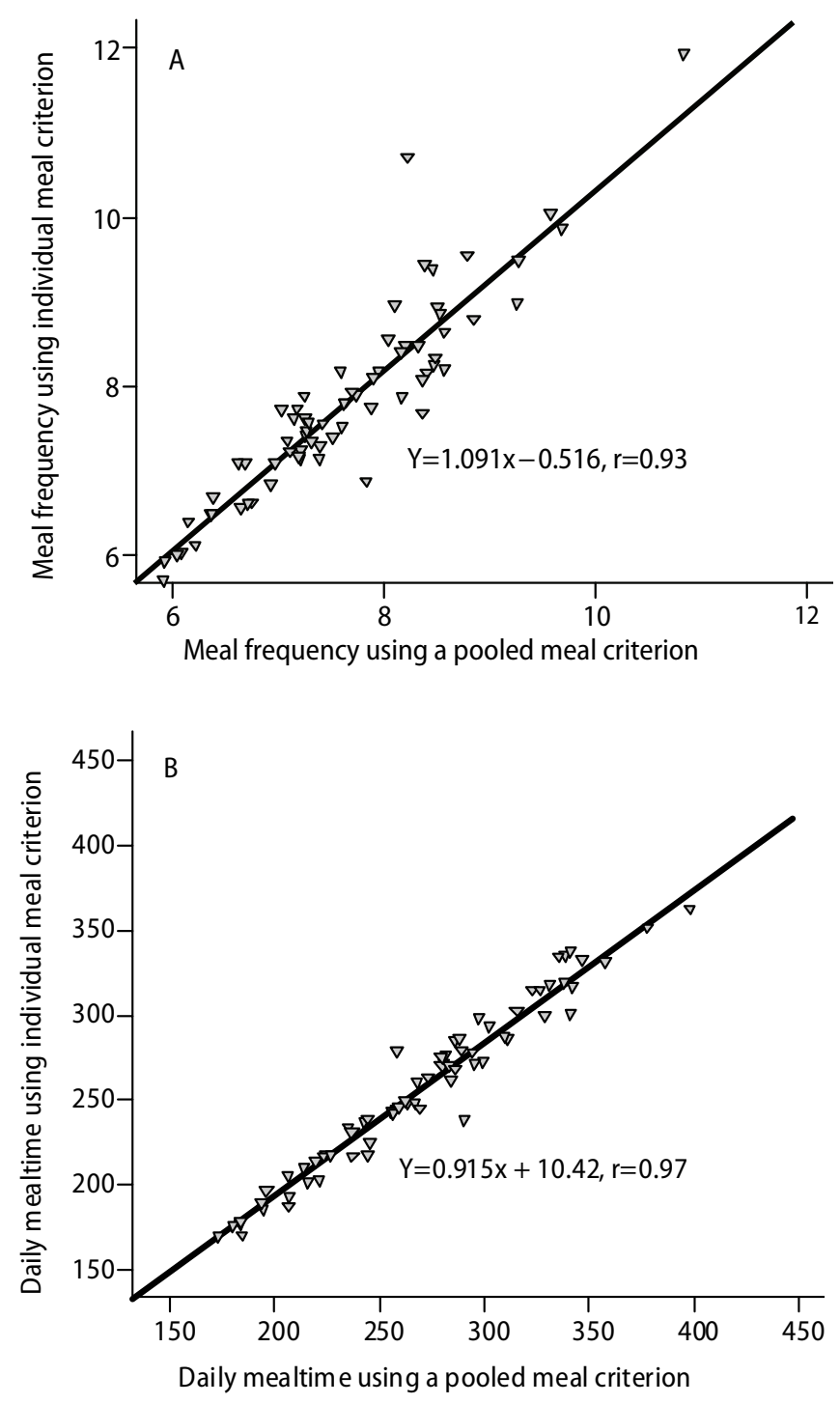

Figure 2

The relationship of meal frequency (A) and daily mealtime (B) calculated with a pooled meal criterion (28.5 min) and with individual meal criterion.

Beziehung zwischen Mahlzeitfrequenz (A) und täglicher Fresszeit (B), kalkuliert mittels eines gepoolten Mahlzeitenkriteriums (28,5 min.) und des individuellen Mahlzeitenkriteriums.

The lactation stages were compared in terms of feeding behaviour characteristics and feed intake parameters (Table). Parity, period and interaction between parity and period had a significant effect on all feeding behaviour characteristics and feed intake parameters. Cows in the 1st lactation had more meals per day than cows in other parities $(P<0.001)$. The meal frequency was significantly decreased in all parities from period 1 to period 3 . The number of visits per meal was significantly different between parities and increased 

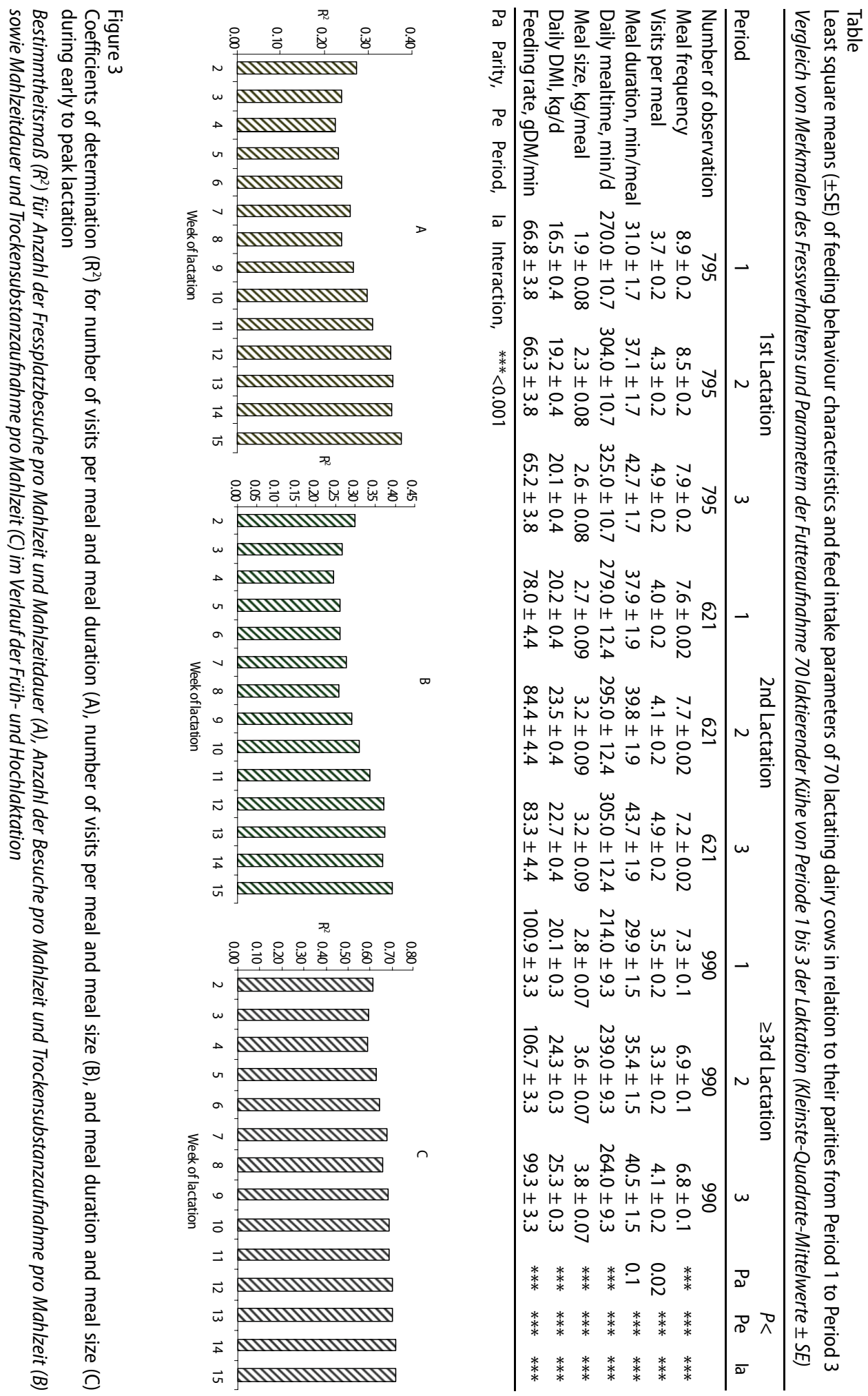
during lactation. There was no significant effect of parity on meal duration $(P<0.01)$.The mean of meal duration rose from period 1 to period $3(P<0.001)$. Cows in the 1st lactation spent an average of approximately $5 \mathrm{~h}$ per day ( 270 to $325 \mathrm{~min}$ ) at the feeders whereas cows in the 3 rd-and-more-lactation spent only $4 \mathrm{~h}$ per day (214 to $264 \mathrm{~min})$ at the feeders. Similar to meal duration, daily mealtime increased from period 1 to period 3 $(P<0.001)$. Cows in the 1st lactation had a smaller meal size than cows in the other parities $(P<0.001)$. Younger cows ( 1 st lactation) had less daily DMI than older cows. Cows in the 1st lactation realised a significant lower feeding rate than older cows.

Over the course of the study, the correlation between the number of visits per meal and the meal duration was significant $(r=0.57, P<0.01)$. However, it was found a low correlation between the number of visits per meal and the meal size $(r=0.14)$. The correlation between meal duration and meal size was significant $(r=0.51, P<0.01)$. The coefficients of determination $\left(R^{2}\right)$ between the number of visits per meal, meal duration and meal size as well as between meal duration and meal size over the time are shown in Figure 3.

Meal duration was significantly related to the number of visits per meal $\left(R^{2}=0.55-0.63\right.$; $P<0.001)$. The relationship between the number of visits per meal and meal size were found from $R^{2}=0.25$ to 0.39 . Meal size during early lactation was highly related to meal duration. Coefficients of determination $\left(R^{2}\right)$ between meal duration and meal size increased from $0.59(P<0.001)$ in the 1st four weeks of lactation to $0.72(P<0.001)$ in the 15 th week of lactation.

\section{Discussion}

Many researchers (TOLKAMP et al. 1998, FRIGGENS et al. 1998, DE VRIES et al. 2003) suggest that the use of meals rather than the visits is appropriate for certain types of analyses, particularly in relation to the short-term regulation of feed intake. This supports the results of the present study, in which data were analysed based on meal criterion and showed higher correlation between feeding behaviour, compared with the results of a previous study (KAUFMANN et al. 2007), where individual visits at the feeders were analysed without calculating the meal criterion. In this study, the meal criteria were similar to meal criteria estimated by other authors. TOLKAMP et al. (1998), TOLKAMP and KYRIAZAKIS (1999), and YEATES et al. (2001) found meal criteria ranging from 26.4 to $63.7 \mathrm{~min}$; YEATES et al. (2001) calculated a meal criterion of $29 \mathrm{~min}$; TOLKAMP et al. (2000) estimated meal criteria ranging from 24 to $28 \mathrm{~min}$ for different groups of cows; DE VRIES et al. (2003) reported $27.7 \mathrm{~min}$ (8.4 to $52.5 \mathrm{~min}$ for individual animals) for the meal criterion from pooled data. DE VRIES et al. (2003) used the pooled meal criterion and found an average meal frequency of $7.3 \pm 1.5($ mean $\pm S D)$ meals $/ \mathrm{d}$, meal duration of $47.1 \pm 13.0 \mathrm{~min} / \mathrm{meal}$, and daily mealtime of $332.3 \pm 69.2 \mathrm{~min} / \mathrm{d}$. TOLKAMP et al. (2000) studied the short-term feeding behaviour of dairy cows from early to mid lactation and reported an average meal frequency of $6.1 \mathrm{meals} / \mathrm{d}$, meal duration of $36.9 \mathrm{~min} / \mathrm{meal}$, and daily mealtime of $225.1 \mathrm{~min} / \mathrm{d}$. The values for meal frequency, meal duration, and daily mealtime found in the current study were similar to those reported by DE VRIES et al. (2003) and TOLKAMP et al. (2000). The present calculation of the meal criterion based on the same method 
described by these researchers. DADO and ALLEN (1994) found a meal frequency of 11.9 meals/d, a meal duration of $25.9 \mathrm{~min} / \mathrm{meal}$, and a daily mealtime of $294 \mathrm{~min} / \mathrm{d}$. However, these results differ from findings of this study regarding meal frequency and meal duration. The variability between the results may be due to different methods of calculation, for example, DADO and ALLEN (1994) used $7.5 \mathrm{~min}$ as the meal criterion. The shorter meal criterion used by DADO and ALLEN (1994) led to a higher meal frequency but did not change the total daily mealtime (DE VRIES et al. 2003). Another possible explanation for these differences may include the difference in experimental conditions. DADO and ALLEN (1994) studied 12 cows on the 63 DIM for 10 days in a tie stall. There was substantial between-cow variation for all characteristics of feeding behaviour for all three time periods. DE VRIES et al. (2003) studied the effect of the stage of lactation (period 1:35 516 , period 2, 57 \pm 16 , and period 3, $94 \pm 16$ [mean \pm SD] DIM) on the feeding behaviour of dairy cows. They found significant differences in feeding behaviour between period 1 and period 2 but no differences between period 2 and 3 . These findings are in agreement with the present results, which showed significant changes in feeding behaviour and feed intake at three different time periods during early lactation. Studies of the feeding behaviour of dairy cows considering the number of lactation showed a great variation. Cows in the 1st lactation tended to have more meals per day and spent more time at the feeder but consumed less than cows in the 3rd-and-more lactation. Older cows consumed more DM per min than younger cows. Only a few studies have compared the differences in feeding behaviour between parity groups. DADO and ALLEN (1994) found a significant difference in DMI between parity groups. Multiparous cows consumed more DM, ate larger meals more quickly, ruminated longer and more efficiently, and drank more water than primiparous cows. BOWMAN et al. (2003) reported that primiparous cows spent more time eating and had a smaller meal size as well as lower DMI compared to multiparous cows. However, the number of meals per day was similar for both parity groups. BEAUCHEMIN and RODE (1994) found that primiparous cows ate more slowly than older cows. This is confirmed by results in this study, which showed that the duration of the daily mealtime of younger cows was increased but the daily DMI was lower compared to older cows. The greater time needed for younger cows to masticate feed ought to be an important consideration for feeding strategies designed to promote DMI. Although the number of visits per meal was similar between cows in the 1 st and 2nd lactation, there was a significant difference between cows in the 1st lactation and cows in the 3rd-and-more-lactation. BOWMAN et al. (2003) found a significant difference in daily time eating ( $347 \mathrm{vs.} 323 \mathrm{~min} / \mathrm{d}$ ) and daily DMI ( $20.50 \mathrm{vs.} 23.00 \mathrm{~kg} / \mathrm{d}$ ) but no difference in the number of meals per day (13.4 vs. 13.5) between primiparous and multiparous cows. Some differences between the present results and findings of BOWMAN et al. (2003) may be partially caused by differences in the definition of visit and meal criterion. BOWMAN et al. (2003) defined a visit as eating activity greater than $30 \mathrm{~s}$ and more than $300 \mathrm{~g}$ of feed being removed from the feeder, and also meals within close proximity had to be greater than $10 \mathrm{~min}$ apart to be considered separate and distinct meals. By contrast, in the current study, a visit was defined as the time spent by an individual cow with her head in one of the troughs, regardless of how the cow spent that time. The visits which separated by intervals shorter than or equal $28.5 \mathrm{~min}$ were grouped 
into meals. Possible explanations for the different results for younger and older cows might be due to differences in rumen volume, and/or that older cows do eat quicker and ruminate for a longer period of time. This fact is also reported by other authors (DADO and ALLEN 1994, BOWMAN et al. 2003). In addition, rumen capacity tends to be smaller for primiparous cows. The meal size may be limited by rumen volume. Behavioural studies suggest that different mechanisms may control individual meals and the total daily DMI of cows (FORBES 1995, BOWMAN et al. 1994, BOWMAN et al. 2003). VAN SOEST (1994) stated that there is a strong relationship between body weight and gastrointestinal capacity in herbivores. Body weight was reported to be the most important factor explaining variation in DMI of 1st lactating cows (KERTZ et al. 1991). The present results regarding the feeding rate (66.09 vs. 81.90 and $102.52 \mathrm{~g} \mathrm{DM} / \mathrm{min}$ for cows in the 1 st-, 2nd-, and 3rd-and-more-lactation, respectively) were similar to findings of DADO and ALLEN (1994) who reported that a feeding rate for multiparous cows was over $80 \mathrm{~g}$ of $\mathrm{DM} / \mathrm{min}$ compared to $69.5 \mathrm{~g}$ of DM/min for primiparous cows. BOWMAN et al. (2003) found also an average feeding rate of $71.9 \mathrm{~g} \mathrm{DM} / \mathrm{min}$ for multiparous cows and $59.4 \mathrm{~g}$ $\mathrm{DM} / \mathrm{min}$ for primiparous cows. Some variation in results among studies may be due to different production levels, behaviour definition description, chemical composition and physical form of the diet, management, and environment (DADO and ALLEN 1994, FORBES 1995). Behaviour at the feeder is often affected by social dominance. Dominant cows tend to spend more time eating in a competitive situation than cows with a lower social rank, if feeder space is restricted (ALBRIGHT 1993). In a competition situation, cows consume more feed but spend less time per day for feed intake (OLOFSSON 1999). In the current study, the ratio of 2 cows per feeder might lead to a competitive situation, which can affect feeding behaviour characteristics. However, JACKSON et al. (1991) found that up to a ratio of 3.5 cows per feeder there was no effect on daily intake.

The relationship between the individual behavioural characteristics indicated several changes in dairy cattle feeding behaviour during early lactation. A relationship between the number of visits per meal, meal duration $(P<0.001)$ and meal size $(P<0.001)$ can be used to predict daily mealtime and daily DMI by recording the number of visits per meal or day. Coefficients of determination between meal duration and meal size during early lactation were high $\left(R^{2}=0.59-0.72 ; P<0.001\right)$. The close correlation between meal duration and meal size could be used to estimate feed intake.

Information concerning the feed intake of each individual dairy cow is especially valuable for herd management particularly during early lactation. Results from the current study, compared with a previous one (KAUFMANN et al. 2007), demonstrated that the identification of a biologically relevant meal criterion for the feeding behaviour of lactating dairy cows is necessary to evaluate visits at the feeders.

\section{Acknowledgements}

The authors gratefully thank the staff of the Centre of Research for Animal Husbandry and Technology of the Regional Office for Agriculture and Horticulture (Iden, Sachsen-Anhalt, Germany). 


\section{References}

Albright JL (1993) Feeding behavior of dairy cattle. J Dairy Sci 76, 485-98

Beauchemin KA, Rode LM (1994) Compressed baled alfalfa hay for primiparous and multiparous dairy cows. J Dairy Sci 77, 1003-11

Bowman GR, Beauchemin KA, Shelford JA (2003) Fibrolytic enzymes and parity effects on feeding behavior, salivation, and ruminal pH of lactating dairy cows. J Dairy Sci 86, 565-75

Dado RG, Allen MS (1994) Variation in and relationships among feeding, chewing, and drinking variables for lactating dairy cows. J Dairy Sci 77, 132-44

DeVries TJ, Von Keyserlink MAG, Weary DM, Beauchemin KA (2003) Measuring the feeding behavior of lactating dairy cows in early to peak lactation. J Dairy Sci 86, 3354-61

Forbes JM (1985) The importance of meals in the regulation of food intake. Proc Nutr Soc Aust 10, 14-24

Forbes JM (1995) Feeding behaviour. In: Forbes JM (ed) Voluntary food intake and diet Selection in farm animals. CAB International, Wallingford, UK, 11-31

Friggens NC, Nielsen BL, Kyriazakis I, Tolkamp BJ, Emmans GC (1998) Effects of feed composition and stage of lactation on the short-term feeding behavior of dairy cows. J Dairy Sci 81, 2368-3277

Gill M, Romney D (1994) The relationship between the control of meal size and the control of daily intake in in ruminants. Livest Prod Sci 39, 13-8

Jackson DA, Johnson CL, Forbes JM (1991) The effect of compound composition and silage characteristics on silage intake, feeding behaviour, production of milk and live weight change in lactating dairy cows. Anim Prod 52, 11-20

Kaufmann O, Azizi O, Hasselmann L (2007) Feeding behaviour of high yielding dairy cows during early lactation. Züchtungsk 79, 219-30 [in German]

Kertz AF, Reutzel LF, Thomson GM (1991) Dry matter intake from parturition to midlactation. J Dairy Sci $74,2290-5$

Nielsen BL (1999) On the interpretation of feeding behavior measures and use of feeding rate as an indicator of social constraint. Appl Anim Behav Sci 63, 79-91

Olofsson J (1999) Competition for total mixed diets fed for ad libitum intake using one or four cows per feeding station. J Dairy Sci 82, 69-79

SAS Institute (2003) User's Guide: statistics Version 9, Cary, NC, USA

Tolkamp BJ, Allcroft DJ, Austin EJ, Nielsen BL, Kyriazakis I (1998) Satiety splits feeding behavior into bouts. J Theor Biol 194, 235-50

Tolkamp BJ, Kyriazakis I (1999) To split behavior into bouts, log-transform the 278 intervals. Anim Behav $57,807-17$

Tolkamp BJ, Schweitzer DPN, Kyriazakis I (2000) The biologically relevant unit for the analysis of short-term feeding behavior of dairy cows. J Dairy Sci 83, 2057-68

Van Soest PJ (1994) Nutritional ecology of the ruminant. 2nd ed Cornell University Press, Ithaca, NY, USA

Yeates MP, Tolkamp BJ, Allcroft DJ, Kyriazakis I (2001) The use of mixed distribution models to determine bout criteria for analysis of animal behavior. J Theor Biol 213, 413-25

Received 27 April 2009, accepted 19 January 2010.

Corresponding author:

LUTZ HASSELMANN

email: lutz.hasselmann@agrar.hu-berlin.de

Division of Animal Husbandry and Technology, Department of Crop an Animal Science, Agricultural and Horticultural Faculty, Humboldt-Universität zu Berlin, Philippstr. 13, Haus 10, 10115 Berlin, Germany 